\title{
DEAREST RACHEL
}

\author{
Sylvia Townsend Warner
}

10: x: 1953

Maiden Newton, Dorset ${ }^{1}$

Dearest Rachel

Nothing could be more congenial to me than a letter about family trees - family groves, rather. The mourning ring will make a good point of departure. It commemorates JANET (not James) SINCLAIR, who died in 1745. She was married to WILLIAM SINCLAIR, of The Braehead, near Thurso. Their daughter, also a JANET, married in 1767, KENNETH SUTHERLAND, who lived in the north-west of the county of that name, and bore him thirteen children. One of these children was EUPHAN (or Euphemia) who in 1790 married GEORGE TOWER.

Janet and Kenneth Sutherland, lived for a time in the Orkneys, and Euphan was born there. Another daughter, Flora, had the name from Flora MacDonald, who was her godmother. (This Flora Sutherland ${ }^{2}$ was godmother to your great grandmother, Flora Moir, and the Flora went on to your grandmother and your mother. It is a good line, and if you marry and have a daughter, I hope you will perpetuate the custom.) Another of the 13 Sutherlands 
was Neill Sutherland, who became a doctor and married MAGDALEN GORDON of Aberdour.

Euphan Sutherland and a sister were sent to the mainland to a boarding school, and the parent Sutherlands, having an introduction to the Towers, an Aberdeen family, asked that a Tower should meet the girls on their arrival. George Tower, then about 20, was sent to do so. The voyage from Caithness had been stormy, Euphan had been sea-sick, and George Tower helped her to stagger off the boat. In spite, or because of this, he fell in love with her.

That covers the SINCLAIRS and the SUTHERLANDS, and the GORDON connection. Now for the TOWERS.

JOHN TOWER, born in 1719 , married MARGARET SCOTT, and had six sons and two daughters. Three of these sons, the eldest, ALEXANDER, and John and James, began the West Indies connection by buying estates there. ALEXANDER came back with a fortune, and bought a place called Logie o'Buchan. ${ }^{3} \mathrm{He}$ was M.P. for Berwick, and a Colonel in the Duke of Gordon's volunteers (Napoleonic threated (sic) invasion). He died in 1813. His daughters were known as the Proud ${ }^{4}$ Miss Towers, to distinguish them from their cousins, the daughters of John Tower (who married a West Indian heiress), and were called the Rich Miss Towers (one of the Rich Miss Towers ${ }^{5}$ married Henry Lumsden of Clova and was painted by Raeburn $)^{6}$. James Tower also had four daughters and they were called The Pretty Miss Towers? ${ }^{7}$.

GEORGE, the fourth son of John and Margaret, stayed at in (sic) Aberdeen, and married Euphan Sutherland, as aforesaid, and died in 1811. (He was born in 1762.) There were ten children of this marriage, but you need only attend to two of them. ALEXANDER, who also went to the West Indies, and whose return to Scotland in 1846 with two negro servants as well as wife and daughters, is probably the origin of that 'very dark wife' legend which has passed into your possession. (I am afraid this is the nearest we come to African relations!) and FLORA (see 
Flora Sutherland and Flora MacDonald) who married, in 1830, your great-great-grandfather, GEORGE MOIR.

The Moirs are an Aberdeenshire family, and have somewhere a Gordon intermarriage; but by the close of the $18^{\text {th }}$ century our Moirs were settled in Aberdeen in the wine trade. GEORGE MOIR's father, also called George, was married to MARY STRATTON ${ }^{8}$. George Moir II (the great-great-grandfather) was the eldest son, born in 1800. He was educated first in the Aberdeen grammarschool, then at the University, ${ }^{9}$ and took his M.A. degree when he was 18. He then went to Edinburgh to read for the Scotch Bar, and was so distinguished as an advocate that he was made professor of Rhetoric in Edinburgh University. He is mentioned in Henry, Lord Cockburn's Memoirs, as being a brilliant orator, 'a respectable classic, well in modern languages, and profound in the literature and philosophy of Germany,' but as being handicapped by an 'irrecoverable Aberdeen accent.' In spite of the accent, he went on to be Sheriff of Rossshire, (sic) Sheriff of Stirling, and Professor of Law at Edinburgh University. He was a friend of Thomas Carlyle, and when Goethe, corresponding with Carlyle about the translation of the Life of Schiller, asked politely what sort of house Ecclefechan (where Carlyle then lived) was, it was George Moir who did the pencil drawing of it. Altogether, he seems to have been a most brilliant and fascinating person, and remarkably more liberal-minded by his wife Flora, who was mentally crippled by the awful piety of her day, and cast a stern shade of hell and Sabbath over the household. They had six children. The first two, a boy and a girl, were exceptionally brilliant, and died very young of scarlet fever, which they caught from their mother who had caught it while visiting the poor (My grandmother said that this was the reason why poor Mrs Moir was so sombre and depressing). The other children were FLORA, ANNE, MARY, and ROBERT; and this was the family that grew up in 41 , Charlotte Square ${ }^{10}$. Only the two elder children married. ANNE married Ponsonby Moore, who later was Earl of Drogheda ". Cousin Bee and Cousin Henry are her children. FLORA 
married GEORGE TOWNSEND WARNER, and their children were GEORGE, my father, FLORA, who married Noel Monckton, and was your grandmother, ROBERT, the family's invaluable Uncle Bertie, and EUPHEMIA, our Aunt Eff.

That concludes the Mourning Ring tree; and by the way, you should take care of that mourning-ring. There are not many of such an early date, and it is definitely a Museum Piece - and perhaps worth a little codicil, bequeathing it, if you should not have a child to inherit, to some museum in Edinburgh or Aberdeen. If you like, I will enquire for a suitable one, since you can't do this so well in Africa ${ }^{12}$.

All this is on your side of the family, here is something you can share with Cousin Kitty.

GEORGE TOWNSEND, born is 1746, and son of another George Townsend, married a Susanna Morris. Among their five children was a daughter, SUSAN, who married JOHN WARNER. The son of this marriage was yet another George, and in 1840, he married SUSAN HOBSON OKE - Dorset family, I believe. They had a son, GEORGE TOWNSEND, who married FLORA MOIR, and a daughter CATHERINE, who married LANCELOT SANDERSON, of Elstree, parents of Ted, Monica, Hallam, Grey, Geraldine, Flora, Eileen, Tottie, Lancelot alias Bunny, and I don't know how many other Sandersons, This Catherine was the celebrated Aunt Kitty, graceful as a willow, full of romance and feeling, who called a succession of sons after the young men who were her devoted and blameless admirers. She and my grandmother Flora - her sister-in-law - went through a phase of genealogical research in pursuit of John Warner. Poor J.W. was known as that wicked young man, and the Townsends had, so to speak, buried him, bringing up George Townsend Warner (Catherine's father) as a sort of impaired Townsend with nothing but an injured mother and good grandparents.

The burial had been so efficient that all Catherine and Flora could unearth was a letter written by John to his wife Susan, from on board a ship, saying that he hoped 
she would not think too bitterly of him. Apparently he was ill at the time and died soon after. I believe there was also a story, but I have never heard the actual evidence for it, that at some time when John Warner was still a bachelor, he went into the assizes in some provincial town and discovered that among the accused was a man had up for poaching, so poor he had no lawyer to plead for him, whereupon John Warner took on his defence and got him acquitted. To do this, he must have been qualified, either as a solicitor or a barrister, I presume. There was a miniature of him (Flora Townsend Warner's copying) which showed him as rather good-looking in the contemporary Byronesque way, dark-haired, and with a rather petulant proud expression. Effie had this copy, and I suppose it was among the set of miniatures she sold. I expect Catherine Sanderson had the original.

As for the Carr-Saunders cousinry, I can't tell you where and how they fit in. So much for the past. As for the present, and the Ulcerated article on Royal Lodge, you should aim at thirty guineas. I got this from Good Housekeeping whenever I did them a middle, and it was what they themselves suggested. If you managed to supply the illustrations. (sic) of course, that would double it. As it is the Royal Family, and the Ulcerated pulsates with loyalty, you might even ask for forty, which would mean less to them than to you and Kathini. The USA address, by the way, is Howard Moorpark, 131, West $47^{\text {th }}$ St. N.Y. C.17.

I am delighted to hear of your rate of pay with the E.A Standard, and I don't doubt you will earn every penny of it. Your memory will improve when you do what you most wisely aim to do: that is, get the business of your father squarely faced and accepted and put away. There is nothing worse for the memory than a half-digested parent, so much is taken up by remembering not to remember. You are brave, and honest, and I am sure you will make a good trim job of it.

My greetings to Cousin Kitty and Kathini.

With my love

Sylvia (signed) 
Don't let yourself by (sic) gobbled up by those six children. It might turn out to be better economy to pay and be your own mistress.

\section{NOTES}

1. Typed letter with date and address handwritten.

2. 'Sutherland' typed above the line and inserted after 'Flora' with MS insertion point.

3. Logie o'Buchan is on the A90 north of Aberdeen. It was allowed to go to ruin when it passed into the hands of Sir Charles Bannerman of Crimonmogate, who bought it from the 'representative of Lieut-Col Tower (before 1888). See

http://www.rattrayhead.net/history/buchanfieldclub.htm 4. 'Rich' crossed out and 'Proud' inserted above the line.

5. Catherine Tower. See Charles Mosley, editor, Burke's Peerage, Baronetage and Knightage, $107^{\text {th }}$ edition, 3 volumes (Wilmington, Delaware, U.S.A.: Burke's Peerage (Genealogical Books) Ltd, 2003) Vol. 1, p.1011. 6. Painting untraced so possibly still in private collection. 7. End of page 1: Down lefthand margin STW added in MS 'I have the earlier volume of my grandmother's memoirs. My father inherited them as the elder son. The second volume was on loan to Uncle B and Aunt Eff [word unclear] it, I have no objection to that, but apparently she also lost it.

8. Straton according to Oxford Dictionary of National Biography.

9. There were two universities - King's College and Marischal College - at this point, though they merged in 1860 , taking the name University of Aberdeen. Moir attended Marischal College $1813-1817$ according to Oxford Dictionary of National Biography. 10. 14 Charlotte Square according to Oxford Dictionary of National Biography.

11. http://www.thepeerage.com/p25436.htm.

12. A tick and the word 'done' added by hand in left hand margin at end of this paragraph. 